REGARDS

SUR L'ECONOMIE ALLEMANDE

BULLETIN ECONOMIQUE DU CIRAC

\section{Regards sur l'économie allemande}

Bulletin économique du CIRAC

$81 \mid 2007$

Varia

\title{
Économie informelle
}

SCHNEIDER Friedrich, BADEKOW Helmut, Ein Herz für Schwarzarbeiter. Warum die Schattenwirtschaft unseren Wohlstand steigert

\section{OpenEdition}

Journals

Édition électronique

URL : http://journals.openedition.org/rea/442

DOI : $10.4000 /$ rea. 442

ISBN : 978-2-8218-0858-4

ISSN : 1965-0787

Éditeur

CIRAC

Édition imprimée

Date de publication : 1 mai 2007

ISSN : 1156-8992

Référence électronique

"Économie informelle », Regards sur l'économie allemande [En ligne], 81 | mai 2007, document 4, mis en ligne le 23 avril 2008, consulté le 22 septembre 2020. URL : http://journals.openedition.org/rea/442 ; DOI : https://doi.org/10.4000/rea.442

Ce document a été généré automatiquement le 22 septembre 2020

(C) CIRAC 


\section{Économie informelle}

SCHNEIDER Friedrich, BADEKOW Helmut, Ein Herz für Schwarzarbeiter. Warum die Schattenwirtschaft unseren Wohlstand steigert

\section{RÉFÉRENCE}

SCHNEIDER Friedrich, BADEKOW Helmut, Ein Herz für Schwarzarbeiter. Warum die Schattenwirtschaft unseren Wohlstand steigert, Econ, Ullstein Buchverlage, Berlin, 2006, 172 p.

1 Non, le travail au noir n'est pas dommageable à l'économie ; au contraire, il génère croissance et emplois. Sous son apparence volontairement provocatrice, l'ouvrage poursuit l'objectif de rompre le cou aux clichés et de ramener le débat, envenimé par la hausse de la TVA, sur un terrain plus factuel. Pour ce faire, le Prof. Schneider (Université de Linz, Autriche), spécialiste réputé de l'économie informelle (il est également chercheur auprès de l'OCDE) s'est associé à un journaliste économique. Le poids du travail dissimulé en RFA ? Plus de 346 milliards $€$ en 2005, soit près d'un cinquième du PIB. La raison de cet engouement des Allemands pour le travail au noir réside dans un niveau de prélèvements trop élevé et dans une régulation trop rigide du marché de l'emploi. Cela plaide pour des réformes structurelles afin de réintégrer ces activités de l'ombre dans l'économie 'officielle'. (ib) 